\title{
Commentary
}

\section{Factoids of Working Life}

\author{
I Jan Ch Karlsson \\ Department of Working Life Science, Karlstad University, Sweden
}

actoids are statements that are repeated so often that they appear as facts even though they are not. I don't know any field that is as full of factoids as working life. And-sadly-there are working life researchers contributing with factoids to what is called the public debate.

When I detect factoids of working life, they have one thing in common: They are portrayed as self-evident truths, but they do not have any data to back them up. For example, it was not long ago when this had become a fact: People in general and youth in particular don't want secure employment any more. Earlier, in the old society, people wanted such security, but now, in the new society, nobody wants it any longer. But the statement was false. It was a factoid. It was spread in mass media, most politicians believed in it, and there were even working life researchers who disseminated it. But it was false. It was a factoid. For those who wanted to see, there were numerous empirical studies of what people really thought about secure jobs. They showed clearly that secure jobs were what people wanted and that there was no difference between age groups. But in the public debate, facts succumbed to the factoid.

Another example: Labor law, especially the Law on Security of Employment, is stricter in Sweden than in other countries and it curtails the rate of employment. It is false. To begin with, Sweden belongs to a middle category of strictness, that is, the degree of security of employment, in international comparison. At the top of the table of strictness, we find France, Portugal, Turkey, and Spain. At the bottom are for example Japan, Denmark, Canada, UK, and USA. And among those in between are Sweden, Norway, Finland, Germany, and Poland. Further, if the statement was true, those countries that have liberalized their labor market laws should have reached a higher level of employment than other countries. But that is not the case. There simply is not any correlation between the strictness of labor law and the degree of employment (Furåker, 2009; Furåker et al., 2007). The statement is a factoid.

A further example: The demands of qualifications in working life have risen to such an extent that people's level of education has not managed to keep up. There is a widespread under-education on the labor market. It is false. In reality, it is the other way around. It is true that there is a big gap between individuals' level of education and the qualification level of the jobs, but it goes the other way as it were: People's level of education has risen to such an extent that qualifications in working life have not managed to keep up. There is a widespread over-education on the labor market (le Grand et al., 2004; Tåhlin, 2007). The statement is a factoid.

It's hard to stop, here is another one: Equal pay threatens jobs: the smaller the wage gap, the lower the level of employment. Sometimes it is also expressed as a big wage gap is favorable to the number of jobs. But however it is formulated it is false. Let us have a look 
at the employment and wage differences in 22 countries during 22 years (Barth \& Moene, 2012). If the statement was true, the level of employment should be lower in countries with a high degree of equality of wages. But it isn't like that. On the contrary, there is a stable pattern of the level of employment being higher in those countries-like the Nordic ones-that have the smallest wage differences. Further, if the statement was true, the percentage of the population in the labor force should be lower where wage equality is high. But it isn't like that. And so on. Independent of which measure we use, it turns out that it is a factoid that bigger wage differences lead to a higher level of employment.

Only one more, I promise. It takes its point of departure in the indisputable fact that young employees get hurt in work to a much higher degree than older employees. The statement says that this is because the young are accident prone; they think they are immortal - they are not conscious enough about risks, they have a dangerous behavior involving risk. But that is false. Youth find themselves at the lowest rung in the workplace hierarchy. They are supposed to perform their work in ways that they do not yet master, in a tempo they cannot yet accomplish. The higher degree of accidents is not due to their individual characteristics but those of the organization. The villain are not the young workers, the villain is the work organization (Nielsen 2012, Nielsen et al. 2013). The statement is a factoid.

Now, I don't think it is very difficult to counteract factoids. The slogan is very simple: Check data, check facts! I'm aware that there have to be some philosophy of science modifications and qualifications of this watchword-but that belongs to the silky skills. The main thing is that we all are a bit critical and reflect on the actual empirical basis of statements of working life-especially if they are conveyed as self-evidently true. We working life researchers have, I suggest, a lot of responsibility to unmask factoids of working life and be self-critical enough not to spread them.

\section{References}

Barth, E. and K.O. Moene (2012) 'Employment as a Price or a Prize of Equality: a Descriptive Analysis.' Nordic Journal of Working Life Studies (2)2: 5-33.

Furåker, B. (2009) 'Unemployment and Social Protection', pp. 17-34 in M. Giugni (ed.) The Politics of Unemployment in Europe. Furnham: Ashgate.

Furåker, B., K. Håkansson and J.C. Karlsson (2007) 'Reclaiming the Concept of Flexibility', pp. 1-17 in B. Furåker, K. Håkansson and J.C. Karlsson (eds) Flexibility and Stability in Working Life. Basingstoke: Palgrave Macmillan.

le Grand, C., R. Szulkin and M. Tåhlin (2004) 'Överutbildning eller kompetensbrist?' [Over-education or lack of competence?], pp. 283-321 in M. Bygren, M. Gähler and M. Nermo (eds) Familj och arbete - vardagsliv i förändring. [Family and Work - Everyday Life in Change]. Stockholm: SNS.

Nielsen, M.L. (2012) 'Adapting “the Normal” - Examining Relations between Youth, Risk and Accidents at Work.' Nordic Journal of Working Life Studies (2)2: 71-85.

Nielsen, M.L., J. Dyreborg, P. Kines and K. Nielsen (2013) 'Exploring and Expanding the Category of "Young Workers" According to Situated Ways of Doing Risk and Safety - a Case Study in the Retail Industry.' Nordic Journal of Working Life Studies (3)3: 219-243.

Tåhlin, M. (2007) 'Överutbildningen i Sverige: utveckling och konsekvenser' [Over-education in Sweden: development and consequences], pp. 70-89 in J. Olofsson (ed.) Utbildningsvägen - vad betyder den? [The Road of Education - What Does It Mean?]. Stockholm: SNS.

Note: The article is built on two of my blogs in Swedish at http://falf.se. 